Lautaro Ríos Âlvarez*

\title{
El Fundamento Axiológico de las Relaciones Internacionales y de las Constituciones Modernas**
}

\section{Introducción}

Los valores -cuyo estudio es el objeto dc la axiologia- son tan antiguos como la humanidad. Pudieron tener diversas denominaciones, así como distinta jerarquía en el seno de las numerosas culturas que han aflorado en la historia del ser humano; pero en todas las épocas han estado allí, activos o latentes, aunque -siempre- guiando el curso evolutivo del género humano, particularmente en sus etapas de crisis.

En la antigüedad, los valores aparecen incardinados en las convicciones religiosas. Así en la cultura judía encontramos los valores en la Torá y, particularmente, en los diez mandamientos recibidos por Moisés en el Monte Sinar. En la antigua Grecia, st arquetipo fue la areté y sus diversas manifestaciones fueron cantadas por Homero en sus poemas épicos. En la cultura cristiana ellos se hermanan con las virtudes y su origen arranca de los Evangelios, especialmente, del Sermón de la Montaña. En la cultura china clásica, los valores fueron recogidos por Confucio en sus Analectas, cuya finalidad principal consiste en la armonía social.

El cercano siglo XX, que fue el escenario de dos guerras mundiales, de la larga y expectante "guerra fria", del nacimiento y declinación de los totalitarismos y de acontecimientos destinados a producir cambios espectaculares en las relaciones entre los seres hurnanos -como los hailazgos de la ciencia y las invenciones tecnológicas $y$, últimamente, la expansión del neoliberalismo y la globalización-, ha sido el escenario permanente de una cncarnizada lucha por la supervivencia de los valores.

Pero esta agonía no ha terminado ni con su muerte ni con su definitiva implanta-

* Doctor en

Derecho, Profesor Titular de Derecho Constitucional, Universidad de Valparaiso. ción en el mundo. El siglo XXI se ha iniciado con el recrudecimiento del terrorismo - paradigma de los antivalores- a escala planetaria. Bajo el pretexto de terminar con él a toda costa y a todo riesgo, una potencia -que se yerguc con la hegemonía del poder

= Trajajo expuesso en el Vi Congreso Mundjal de Derecho Constitucional (Santago de Chile, 12 a ló de enero 2004). 
económico, político y bélico a nivel mundial- se ha arrogado el derecho de invadir y dominar militarmente a otros páses, de derribar sus gobiennos y de decidir su destino polftico, atropellando asi valores, principios y normas fundarnentales del derecho internacional y erosionado las bases que justifican la existencia y la eftcacia de la Organización de las Naciones Unidas.

De allí que sea un hecho, tan sorprendente como real, que los valores siguen estando en crisis desde los inicios de este siglo.

$Y$ es por ello que intentaremos en este breve ensayo, definir los valores; demostrar la relevancia que ellos han adquirido al servir de fundamento a los Pactos Internacionales y a las Constituciones Políticas modernas; la trascendencia que encarna este fenómeno; asi como el peligro que representaría su degradación -esto es, la desvalorización de los valores-en la cultura occidental.

\section{La Reflexión Axiológica en los Siglos XIX y XX}

1. La iniciación de la axiología como "filosofla de los valores" se atribuye a Rudolph H. LOTZE, filósofo y fisiólogo alemán, quien enseñó en Leipzig, Gotinga y Berlín ${ }^{\text {. }}$.

Según los axiólogos, la ontología -o estudio del ser- no agota el mundo de lo existente. La belieza, la justicia, la salud, la santidad, la abnegación, no tienen existencia por sí mismas, pero tampoco son meras ficciones. Son "valores" y pertenecen al campo de la axiología (de) griego "Axios"; justo o valioso) que no estudia "lo que es" sino "lo que vale".

Esto no quiere decir que los valores no existan. No puede concebirse que entidades tan evidentes como los valores, valgan si no empezanos por reconocer su existencia. La tienen, pero en el universo propio de los entes abstractos al que pertenecen, como también ocurre con el número, la velocidad o el triángulo.

El Diccionario de la Lengua Española define el valor, en su sentido filosófico, como "Cualidad que poseen algunas realidades, consideradas bienes, por lo cual son estimables. Los valores tienen polaridad en cuanto son positivos o negativos, y jerarquía en cuanto son superiores o inferiores."

Las propiedades esenciales de los valores serían las siguientes: A: requieren siempre de una realidad -un ser, una cosa, un acto, una conducta- en la cual encarnarse, es decir, requieren un soporte concreto. B: Poseen un contenido estimable que los hace valiosos y, a la vez, los distingue entre ellos. C. Están provistos de polaridad; es decir, a cada valor (polo positivo) corresponde un antivalor (polo negarivo); así, al bien se opone el mal; a la justicia, la injusticia; a la belleza, la fealdad. D: Entre ellos existe una jerar-

1 LOTZE (1817-1881) formuló una concepción finalista del mundo a la que subordina el mecanismo de las ciencias naturales. Trata la axiologia en su "Sistema de Filosofia", escriro entre 1874 y 1879.

2 Diccianario de la Real Academia Espafiola, XXII ed., Ed. Espasa, Madrid, 2001. 
quia; no son todos igualmente estimables sino - por el contrario- admiten una gradación de superior a inferior ${ }^{3}$. E: Cada uno de ellos acepta grados de intensidad, mayor o menor. F: Son irracionales, en el sentido de no ser aprehensibles por la sola razón, sino más bien por la intuición, en una experiencia emotiva, personal y concreta de quien los percibe. G: Lo más importante es que poseen una alta carga afectiva; vale la pena luchar por ellos incluso con el riesgo o el sacrificio de la vida como ha sido el testimonio de Sócrates, de Espartaco, de Tomás Moro, de Mahatma Ghandi, de Nelson Mandela o de Martin Luther King, entre tantos otros. ${ }^{4}$

2. Entre los cultores de la axiología surgieron dos corrientes: la de los "subjetivistas", quienes consideran el valor como un fenómeno psíquico que ocurre al interior del sujeto que lo experimenta, de tal manera que el valor no existe sin un sujeto que lo perciba. Y la de los "objetivistas" que conciben el valor como una realidad objetiva y distinta del sujeto que lo experimenta Así, aquélios hablan de la percepción o la experiencia axiológica; y éstos, en cambio, hablan de un horizonte o un cielo axiológico. Entre los primeros militan Meinong, Ehrensfels, Müller-Freinfels, Henke. Entre los segundos, Rickert, Max Scheler, Ortega y Gasset, Unamuno, Recasens Siches y Hartman.

3. No es ésta la ocasión propicia para referimos a las numerosas discrepancias surgidas en el terreno de la axiología, como la disputa entre los "absolutistas", que ven los valores como bienes definitivamente cristalizados y universalmente apetecidos, y los "relativistas" que los consideran ideales propios de cada cultura y -por ende- variables, según las circunstancias del tiempo y el luggar en que afloran en la sociedad.

Interesa, en carnbio, dilucidar en qué esfera de la vida humana se sitúan los valores.

La polaridad y la jerarguie son distinivos que rescata el Diecionario de la Lengua Espafiola. La jerarquia aparece en la Conscitución española que consagra los valores superiores de su ordenamiento jurídico (art. 1.1.)

4 Sobre los valores, ver José ORTEGA Y GASSET; "Obras Complecas", Alianza Edit., Madrid, 1979, c. VI: "Intro. ducción a una Estimativa”, pgs. 315 y ss. Luis RECASENS SICHES: "Introducción al Estudio del Derecho", Ed. Porría, México, 1981, pgs. 10 y ss. y 275 y ss. Pablo LUCAS VERDU: "Estimativa y Política Constirucionales", Fac. de Derecho - L. Complurense, Madrid, 1984. Jorge 1. HUBNER: "Manual de Filosofia del Derecho", Ed. Juridica de Chilc, Stga., 1954. Anronio HER NÁNDEZ GIL: "Sistema de Valores en la Constitución", en "La Constirución de la Monarqufa Parlanentaria", Fondo de Culaura Económica, Ḿ́xico, 1983, y "El cambio polírico y la Consticución", Ed. Planeta, Barcelona, 1982. Gregorio PECES BARBA "Los Valores Superio. res, Tecros, Madrid, 1986. Joaquin RUIZ-GIMÉNEZ: “Derechos Fundanentales de la Persona (art. 10)", en "Comentarios a la C.E. de 1978", EDERSA, 1997, t. II, pgs. 37-89. Francisco RUBIO LLOREN"1'E: "Constirución: Valores, Principios, Derechos" en "Valores de una Sociedad Plura", Fundación para el Análisis y los Est. Sociales, Madrid, 1999, p8s. 135-148, y "Derechos Fundamentales y Principios Constincionates", Aricl - Derecho, Barcelona, 1995. Luciano PAREJO: "Constitución y Valores del Ordenamicnto", en "Estudios sobre la Constitución Española" - Homenaje al Prof. Eduardo Garcia de Enterria, x. 1, pgs. 29-133. Antonio PÉREZ LUNO: "Derechos Humanos, Estado de Derecho y Constimción", Tecnos, Madrid, 1984. Luis PRIETO SANCHIS: "Los valores superiores del ordenamiento jurídico y el T,C." Rev. Poder Judicial N'o I I, junio 1984. Ángel GARRORENA MORALES: "EI Estado cspañol como Estado social y democrático de derecho", Tecnos, Madrid, 1984. Francisco FERNANDEZ SEGADO: "El Sistema Constirucional Españo]", Dykirson, Madrid, 1992. Jaime BRUEAU: "Tcorfa Fundamenfal del Derecho", lecnos, Madrid, 1990, pg. 76. Angel LLAMAS C.: "Los valores juridicos como ordenamiento materia", BOE. Madrid, 1993. José L. CEA EGANA: "Tratado de la Constitución de 1980", Ed. Jurídica de Chile, Stgo., 1998, pgs. 40-42. 
A comienzos del s. XX Oswald Spengler estremeció al mundo intelectual con su ópera prima, "La Decadencia de Occidente" ". Dejando a un lado sus fantasías nacionalistas -como la superioridad de la raza aria, su estirpe heroica y su vocación mesiánica-, Spengler supo encontrar en la CULTURA a la verdadera protagonista de la historia, a diferencia de los acontecimientos fechados, pueblos y lideres, que habían sido la base material de los historiadores clásicos.

La cultura -esto es, "un cierto modo orgánico de pensar y sentir", en palabras de Ortega, la actitud vital del hombre frente al cosmos, como diría Max Scheler, o el "Conjunto de conocimientos que permite a alguien desarrollat su juicio crítico" (R. Acad.), constituye la aventura impredecible de cada pueblo, de la cual la historia es sólo su relato. Por lo tanto no existirla una sola historia lineal de la humanidad, sino tantas historias corno culturas han logrado florecer en los diversos pueblos. Cada cultura sería un organismo vivo que tiene su nacimiento, su crecimiento, su culminación, su declinación y su muerte ${ }^{6}$.

Ya Nietzsche había hecho la distinción entre Kultur y Zivilisation. Esta última no sólo consistiría en el desarrollo material alcanzado por cada pueblo ni sería el producto final de su evolución social -como créan los racionalistas- sino que también comportaría el inicio de la corrupción y la decrepirud de aquélla.

Y así como los valores encarnan los ideales y sentimientos positivos de cada cultura, la "transvaloración de todos los valores" 7 -esto es, la inversión de las formas de la cultura, alterando su inteligencia, su manejo y su interpretación- representa "el más intimo carácter de toda civilización", que termina destruyéndola ${ }^{8}$.

4. Cabe advertir que, en la época en que Spengler desarrolló sus tesis, el género humano estaba dividido por fronteras geográficas y culturales infranqueables; y su

5 El libro se publicó en Alemania en I 918 pero se comenzo a escribir en 1911 y ya estaba concluido cuando escalló la primera guerra musdial. la primera versión en español apareció en 1923 y fue prologada por José Orrega y Gassct, quict lo calificó como "la peripecia intelectual más estruendosa de tos útimos afios".

6 Dice Spengler, "La 'humanidad' no riene un fin, una idea, un plan; como no tiene fin ni plan la especie de has mariposas o de las arquideas. 'Humanidad' es un concepto zoológico o una palabra vana (idea de Goethe). Que desaparezca erse fantasma del circulo de problemes teferentes a la forma histórica, y se verár surgir con sorprendente abundancia las verdaderas formes. Hay aquí una insondable riqueza, profundidad y movitidad de to viviente, que hasta ahora ha permanecido oculta bajo una frase vacia, un esquema seco, o unos 'ideales' personaies. En lugar de la monórona imagen de una historia universel en linea recta, que sólo se mantiene porque cerramos los ojos ante el número abrumador de los hechos, veo yo el fenómeno de múlriples culturas poderosis, que florecen con vigor cósmico en el seno de una tierra madre, a la que cada unz de ellas estro unida por todo el curso de su existencia. Cada una de estas culruras imprime a su materia, que es el hombre, su forma propici, cada una tiene su propia idea, sus propias pasiones, su propiz vide, su queres, su sentir, su morit propios. Hay aqui colores, luces, movimicntos, que ninguna contemplación intelecrual ha descubierto aún. Hay cutturas, pueblos, idiomas verda. des, dioses, paisajes, que son jóvenes y florecientes; otros que son ya viejos y decadentes; como hay robles, tallos, ramas, hojas, flores, que son viejos y orros que son jóvenes. Pero no hay 'humanidad vieja'. Cada culturz posec sus propias posibilidades de expresión, que germinan maduran, se marchican y no reviven jernés". (Ob. cit.. EspasaCalpe, Madrid, 1983, tono l, pg, 48).

7 Expresión acuñada por Nietzsche y reclaborada por Spengier.

8 "La Deczdencia..." cit., tomo I, pg. 440. 
mérito consistió en haber derribado los mitos existentes acerca de la unidad y la continuidad lineal de la historia o de la universalidad y progresión permanente de la cultura, a modo de ejemplos.

No obstante lo cual, preciso es reconocer la identidad esencial del ser humano en las diversas épocas y en el prodigioso abanico de todas las culturas. Y si así no fuera, no podráamos tener como referente de éstas a la humanidad. Y si son elementos esenciales de esa identidad su capacidad racional, su voluntad y su sensibilidad que le permite amar y sentir, no podemos negar que el ser humano, sin perjuicio de su propia evolución y de las diferencias típicas de la cultura y lugar en que le haya tocado vivir, ha podido tener -a todo lo largo de su historia- aspiraciones e ideales semejantes. No es igual la vivencia de la democracia en Atenas, que en lnglaterra, los Estados Unidos o la India; pero la idea-fuerza de la democracia es semejante. No es idéntica la justicia de Salomón a la justicia de Dracón, ni éstas a la del pretor romano; ni todas las anteriores, a la justicia espańola, la francesa, la argentina o la chilena de nuestros días, pero el ideal o la aspiración cultural de justicia es sorprendentemente semejante.

Y si así no fuera, ¿qué sentido tendría hablas de la iguablad en los tratados internacionales de derechos humanos?

Lo que nos lleva a otro punto que también nos aparta de la concepción spengleriana. Aun concediendo que cada cultura sea un organismo parecido a las especies vegetales que brotan, crecen, se marchitan y mueren, en éstas no existe transmisión genética aprovechable por otras especies. En cambio, los valores culturales no sólo son apetecidos por otras culturas de inferior grado de desarrollo, sino que tienden a ser adoptados y adaptados por éstas a sus propios requerimientos. Roma no sólo se apropió de los dioses de Troya -salvados por Eneas- sino también de los valores éticos, jurídicos, urbanísticos, artísticos y sociales de Atenas. La cultura británica y sus valores políticos y morales han impregnado culturas tan distintas y distantes como las de India y Pakistán.

5. Ya en la primera mitad del siglo XX quedó demostrado, con la Sociedad de las Naciones y la Organización de las Naciones Unidas, que existen unos valores y unos requerimientos de las personas y de los pueblos, que son comunes a toda la humanidad. La explosión demográfica, el incremento a titmo exponencial de las relaciones internacionales de todo orden y el fenómeno irreversible de la globalización han terminado de convencernos que la humanidad no es una abstracción sino un organismo viviente que protagoniza la crónica de cada día y cuyos más graves problemas se proyectan al futuro; y de allí -a modo de ejemplos- los esfuerzos de las naciones cultas por detener la contaninación del medio ambiente y abogar por un desarrollo económico sustentable.

Viene, pues, produciéndose - al menos, desde mediados del pasado sigio- una universalización de la cultura, hermanada con la de los derechos humanos, y una expansión perceptible de los valores que emanan de aquélla y que sirven a éstos de fundamento. 
Cabe advertir también que, siendo los valores la condensación de los más caros ideales de la cultura de cada pueblo, ellos permean no sólo el derecho o la política, sino cada manifestación de la vida social. Así también las bellas artes, la investigación científica, la medicina, la tecnología, la diplomacia y cuantas expresiones de la cultura y de la vida social seamos capaces de identificar, están impregnados de los valores adecuados a su naturaleza, que constituyen su cauce y marcan sus límites de tal manera que, cuando éstos decaen o se transgreden, la respectiva actividad pierde su rumbo y termina corrompiéndose.

En este trabajo nos referiremos a los valores propios de nuestra disciplina, es decir, a los valores jurf́dicos; sin perder de vista que en nuestra cultura occidental existen otros valores de tan noble estirpe como el amor, la belleza, la abnegación, la sabiduría, la humildad, el heroismo y tantos otros ideales estimables, que escapan del ámbito de lo jurídico no obstante que lo enriquecen.

Llamaremos valores jurídicos a aquellos que pueden expresarse en fórmulas exigibles a los dernás, que son garantizables por el Estado y susceptibles de tutela judicial. Entre éstos puede mencionarse la libertad, la justicia, la igualdad, la solidaridad, el Estado de derecho, la democracia y el pluralismo político, como valores relevantes de nuestra época.

\section{El Fundamento Axiológico de las Relaciones Internacionales y del Derecho Internacional de los Derechos Humanos}

En las relaciones internacionales operan Estados que se vinculan o pactan directamente entre ellos o bien lo hacen a través de organizaciones creadas en virtud de la voluntad común de los Estados mediante un tratado multilateral.

Haremos aquí una sucinta relación de las organizaciones y de los tratados en que, a partir del siglo XX, se advierte una clara actitud de exaltación de los valores.

\section{La Sociedad de Naciones}

Concluida la Primera Guerra Mundial (1918) se celebra, entre las potencias vencedoras, el Tratado de Versalles, el 28-VI-1919. Su más preciado fruto es la Sociedad de Naciones (S.D.N.) que nace al entrar aquél en vigor, el 10 de enero de 1920 , fijándose su sede en Ginebra.

La misión de la S.D.N. -con el apoyo de los 32 Estados fundadores? más trece Estados miembros invitados- fue establecer un nuevo orden internacional fundado en el valor justicia, que tendria como objetivos garantizar la paz y la seguridad internacionales.

9 Estados Linidos, pese a la intervención decisiva del Presidente W. Wilson en su gesración, quedó fuera de la S.D.N. por haberse negado el Senado a ratificat el Tratado de Versalles. 
Puede decirse que la S.D.N. dejó dos grandes legados en materia de justicia: la Organización Internacional del Trabajo, generadora de notorios progresos en la condición del mundo laboral, y la Corte Internacional de Justicia con sede en La Haya.

En cambio, resultó impotente para mantener la paz y garantizar la seguridad. Diversos acontecimientos históricos que comienzan con la invasión de Etiopla por otro Estado miembro, Italia, y que culminan con la Segunda Guerra Mundial, pusieron término a sus funciones, las que fueron transferidas a la Organización de las Naciones Unidas (ONU) en sesión solenne del 8/18-IV-1946, desapareciendo oficialmente el 31-VII-1947.

\section{La Organización de las Naciones Unidas}

Al término de la Segunda Guerra Mundial se reúnen en la ciudad nortamericana de San Francisco los representantes de cincuenta Estados -entre ellos, las potencias vencedoras en el conflicto bélico-y suscriben la "Carta de las Naciones Unidas" (26-VI1945) que da origen a la Organización de las Naciones Unidas (ONU) y que entra en vigencia el 24 de octubre del mismo año ${ }^{10}$.

Del Preámbulo de la Cartall y de su Capítulo I que establece sus "Propósitos y Principios", puede colegirse la proclamación y defensa de los siguientes valores, en el mismo orden en que aparecen en la Carta:

- la fe en los derechos fundamentales del ser humano;

- la dignidad y el valor de la persona humana;

- la igualdad de derechos de hombres y mujeres y de las naciones grandes y pequeñas;

- la creación de condiciones para el mantenimiento de la justicia y el respeto a las obligaciones internacionales;

- el progreso social y la elevación del nivel de vida dentro del concepto más amplio de la libertad;

- la práctica de la tolerancia;

- la convivencia en paz y buena vecindad;

- el mantenimiento de la paz y la seguridad internacionales;

10 Al 10 de enero de 2003 la ONL. Registraba 188 Estados Miembros y 5 Estados no miembros hablan suscrito uno o thás de los instrumentos internacionales de DD.HH

11 El Preámbulo dice ast: "Nosotros, los pweblos de las neciones unidas, reruelos a prescrvar a las generaciones venideras del flagelo de la guerra, que dos veces durante nuesera vida ha infligido a la humanidad sufrimientos indecibles, a reafirmar la fe en los derechos fundamentales del hombre, en la digntidad y el valor de la persona humana, en la igualdad de derechos de hombres y mujeres y de las naciones grandes y pequenias". 
El art. 1.3. de la Carta fomenta el valor solidaridad al señalar como propósito de la ONU "Realizar la cooperación internacional en la solución de problemas internacionales de carácter económico, social, cultural o humanitario".

Su art. 2 prescribe que la Organización "está basada en el principio de la igualdad soberana de todos sus Miembros"12 y que tanto éstos como aquélla "cumplirán de buena fe las obligaciones contraídas ... de conformidad con esta Carta"; obligándose a arreglar sus controversias por medios pacíficos "de tal manera que no se pongan en peligro ni la paz ni la seguridad internacionales ni la justicia".

Contiene, además, la siguiente prohibición en armonía con los principios, valores y propósitos que sustenta la Carta: Art. 2.4. "Los Miembros de la Organización, en sus relaciones internacionales, se abstendrán de recurrir a la amenaza o al uso de la fuerza contra la integridad territorial o la independencia política de cualquier Estado, o en cualquier otra forma incompatible con los Propósitos de las Naciones Unidas".

Las contradicciones estatutarias y la débil o infructuosa reacción de la ONU y de su Consejo de Seguridad frente a conflictos internacionales de su incumbencia, dejan débiles esperanzas respecto de su futuro ${ }^{13}$.

\section{La Declaración Americana de los Derecbos y Deberes del Hombre y el Sistema Interamericano de protección de los Derechos Humanos}

Señala la Ptof. Cecilia MEDINA que "El continente americano, al igual que el resto del mundo, reaccionó con mucha fuerza a los efectos devastadores de la Segunda Guerra Mundial"'4. Ya a comienzos de 1945 -año del término de la guerra- se realizó en ciudad de México la Conferencia Interamericana sobre "Problemas de la Guerra y de la Paz". El 30-III-1948 se aprobó la Carta de la Organización de Estados Americanos (OEA) por la IX Conferencia Internacional Americana de Bogotá (Colombia) y el dos de mayo del mismo año vio la luz la "Declaración Americana de los Derechos y Deberes del Hombre", la que es anterior y sirvió de antecedente a la Declaración Universal aprobada por la ONU en diciembre de ese año ${ }^{15}$.

12 O la "igualiad soberana" de los Estados MIEMBROS consiste en el mismo dercho a participar en condiciones iguaies en todos sus órganos y a que el voto de cada uno tenga el mismo valor que el de las demás, o se crata de una igualdad rerórica y -por ende. falsa. Atenta contra el príncipio señalado cl desigual derecho de los "miembros permanentes" del Conscjo de Seguridad y el de los demás tnicrabros no permanentes. Pero principalmente, atenta contra este principio el derecho de veto de aquélos en la decisión de las cuestiones suscantivas del Conscjo de Seguridad (arrs. 23 y 27).

13 La invasión de un Estado Miembro como Iraq, por otro Estado Miembto como LiS.A, con pretextos que resujaron falsos, sin la zutorización del Consejo de Seguridad, con el derrocamiento de su gobiemo, un despliegue abrumador de fuerzas de ataque que destruyó gran parte de su capital, otras ciudades importantes y ocasionó la muerte de muchos civiles, así como la ocupación c interveneión palítica y económica del pals agredióo, significan -a mi juicio- una grave crisis del sistema de la ONU y desvirtúa sus bases y propósitos.

14 Cecilia MEDINA: "Derecho Internacional de los Derechos Humanos", Univ. Academia de Humanismo Cristiano, Srgo., 1990, pg. 139.

15 A modo de ejemplo, el primer párrafo del Preámbulo de la Dectaración Americana conticne un texto similar al Art. $1^{\circ}$ de la Declaración Universal. 
Entre los fundamentos axiológicos de la Declaración Americana merecen ser destacados los siguientes Considerandos:

"Que los pueblos americanos han dignificado la persona humana y que sus constituciones nacionales reconocen que las instituciones jurídicas y polfticas, rectoras de la vida en sociedad, tienen como fin principal la protección de los derechos esenciales del hombre y la creación de circunstancias que le permitan progresar espiritual y materialmente y alcanzar la felicidad;

"Que, en repetidas ocastones, los Estados americanos han reconocido que los derechos esenciales del hombre no nacen del hecho de ser nacional de determinado Estado sino que tienen como fundamento los atributos de la persona humana;"

El Preámbulo de la Declaración Americana fundamenta el cumplimiento de los "Deberes del Hombre", potencia la supremacía del espíritu y pronueve el desarrollo de la cultura.

Dice ass:

"Todos los hombres nacen libres e iguales en dignidad y derechos y, dotados como están por naturaleza de razón y conciencia, deben conducirse fraternalmente los unos con los otros.

"El cumplimiento del deber de cada uno es exigencia del derecho de todos. Derechos y deberes se integran correlativamente en toda actividad social y política del hombre. Si los derechos exaltan la libertad individual, los deberes expresan la dignidad de esa libertad.

"Los deberes de orden jurídico presuponen otros, de orden moral, que los apoyan conceptualmente y los fundamentan.

"Es deber del hombre servir al espíritu con todas sus potencias y recursos porque el espiritu es la finalidad suprema de la existencia humana y su máxima categoráa.

"Es deber del hombre ejercer, mantener y estimular por todos los medios a su alcance la cultura, porque la cultura es la máxima expresión social e histórica del espíritu.

"Y puesto que la moral y las buenas maneras constituyen la floración más noble de la cultura, es deber de todo hombre acatarlas siempre." I6

El Sistema Interamericano de Protección de los Detechos Humanos comprende las fuentes del llamado "Derecho Internacional de los Derechos Humanos" y, entre ellas, las Declaraciones y Tratados vigentes en esta materia, as como los órganos y procedimientos destinados a resguardar efectivamente el respeto a tales derechos.

16 Ver Jorge I. HÜBNER: "Banorama de los Derechos Humanos", Ed. Andrés Bello, Stgo., 1973, pgs. 51 y ss. y 173 y ss. 
La Convención Americana sobre DD.HH. de 22 de noviembre de 1969 (Pacto de San José de Costa Rica) es el fundamento más sólido y completo del Sistema. Ella comprende los deberes de los Estados Partes en relación con los derechos, libertades y garantías que la Convención reconoce a las personas. Luego ella establece los "Medios de la Protección", que consisten en los órganos competentes para conocer de las denuncias o reclamaciones que se presenten ante ellos, y en los procedimientos respectivos. Los órganos son: la Comisión Interamericana de Derechos Humanos ante la cual puede comparecer cualquier persona, grupo o entidad no gubernamental legalmente reconocida (art. 44); y la Corte Interamericana de Derechos Humanos, ante la cual sólo la Comisión y los Estados Partes están habilitados para someter un caso a su decisión (art. 61.1).

No obstante el profundo contenido humanista de la Declaración Americana y de los Pactos referidos, a 56 años de la aprobación de aquélla, los ideales que proclama continúan en el mundo de las buenas intenciones, las que -según el refrán-pavimentan el suelo del infierno.

Para emerger del subdesarrollo -que es el lastre que aplasta la dignidad de una parte considerable de nuestros pueblos- los páses iberoamericanos requieren de una voluntad política única e inquebrantable. Necesitan liberarse de la hegemonfa del Gran Hermano del Norte; $y$, junto con derribar sus fronteras, poner término a las querellas aldeanas que les vienen separando desde la época de la Independencia. Sólo una Iberoamérica unida -es decir, los Estados Unidos de Iberoanérica- podrá compartir sus tecursos y adquirir la tecnología necesaria para evadirse del subdesarrollo y conquistar el peso político del que ahora carece a fin de negociar con otras potencias en condiciones de igualdad, logrando así la calidad de vida necesaria para que sus pueblos puedan vivir con dignidad. ${ }^{17}$

\section{La Declaración Universal de Derechos Humanos}

Esta Declaración -que es universal potque representa el anhelo común "de todos los miembros de la farnilia humana - constituye a la vez un grito de alerta ante los ultrajes escarnecedores sufridos por muchos seres humanos a raíz de la Segunda Guerra Mundial -puestos en relieve en los procesos de Nüremberg-y una interpelación a los Estados Miembros de la ONU para promover el respeto a la dignidad y el valor de la persona humana con miras a construir un mundo pacífico en que impere la igualdad, la justicia y la libertad.

Su Preámbulo dice así:

"Considerando que la libertad, la justicia y la paz en el mundo tienen por base el reconocimiento de la dignidad intrínseca y de los derechos iguales e inalienables de todos los miembros de la fanilia humana,

17 Ver nuestro "Globalización, Integración y Derecho Consritucional" en Estudios de Teoría del Estado y Derecho Constiucional en honor de Pablo Lucas Verdú, Servicio Publicaciones, Fac. de Derecho. Univ. Complutense de Madrid, 200I, t. II, pgs. 1.261 y ss. 
"Considerando que el desconocimiento y el menosprecio de los derechos humanos han originado actos de barbarie ultrajantes para la conciencia de la humanidad; y que se ha proclamado, como la aspiración más elevada del hombre, el advenimicnto de un mundo en que los seres humanos, liberados del temor y de la miseria, disfruten de la libertad de palabra y de la libertad de creencias,

"Considerando esencial que los derechos humanos sean protegidos por un régimen de Derecho, a fin de que el hombre no se vea compelido al supremo recurso de la rebelión contra la tiranía y la opresión,

"Considerando también esencial promover el desarrollo de relaciones amistosas entre las naciones,

"Considerando que los pueblos de las Naciones Unidas han reafirmado en la Carta su fe en los derechos fundarnentales del hombre, en la dignidad y el valor de la persona humana y en la igualdad de derechos de hombres y mujeres; $y$ se han declarado resueltos a promover el progreso social y a elevar el nivel de vida dentro de un concepto más alto de la libertad,

"Considerando que los Estados Miembros se han comprometido a asegurar, en cooperación con la Organización de las Naciones Unidas, el respeto universal y efectivo a los derechos y libertades fundamentales del hombre, $y$

"Considerando que una concepción común de estos derechos y libertades es de la mayor importancia para el pleno cumplimiento de dicho compromiso,

"La Asamblea General

"Proclama la presente Declaración Universal de Derechos Humanos como ideal común por el que todos los pueblos y naciones deben esforzarse, a fin de que tanto los individuos como las instituciones, inspirándose constantemente en ella, promuevan, medjante la enseńanza y la educación, el respeto a estos derechos y libertades y aseguren, por medidas progresivas de carácter nacional e internacional, su reconocimiento y aplicación universales y efectivos, tanto entre los pueblos de los Estados Miembros como entre los de los territotios colocados bajo su jurisdicción".

Pese a los cincuenta y seis años transcurridos desde la fecha de su aprobación, la Declaración Universal no ha perdido su vigor ni su vigencia. Por el contrario, ella no sólo ha sido adoptada por todos los nuevos miembros de la ONU, sino también forma parte integrante, con rango constitucional -junto con la Declaración Americana y otros instrumentos internacionales-, de Cartas Políticas de renovación reciente ${ }^{18}$ y sirve de fuente interpretativa de los derechos y libertades en otras Constituciones ${ }^{19}$.

18 Ver el art. 75 № 22 , inc. 20 de la Conscitución argentina, reformada en 1994.

19 Ver el art. 10.2 de la Conscitución espafioia de 1978. 
Razón tenía el filósofo español José Ortega y Gasset cuando đjjo -allá pot 1923-que “... la preocupación teórica y práctica en torno a los valores es uno de los hechos más hondamente reales del tiempo nuevo". Añadiendo luego que "se trata de una de las más fértiles conquistas que el siglo XX ha hecho $\mathrm{y}$, a la par, de uno de los rasgos fisiognómicos que mejor definen el perfil de la época actual ${ }^{20}$.

\section{La Convención Europea y el Sistema Europeo de Protección de Los Derechos Humanos}

La Convención Europea está fechada en Roma el 4 de noviembre de 1950.

Comienza con la siguiente fundamentación:

"Los Gobiernos signatarios, miembros del Consejo de Europa,

"Considerando la Declaración Universal de Derechos Humanos, proclamada por la Asamblea General de las Naciones Unidas el 10 de diciembre de 1948;

"Considerando que esta Declaración tiende a asegurar el reconocimiento y la aplicación universales y efectivos de los derechos en ella enunciados;

"Considerando que la finalidad del Consejo de Europa es realizar una unión más estrecha entre sus miembros, y que uno de los medios para alcanzar esta finalidad es la protección y el desarrolio de los derechos humanos y de las libertades fundamentales;

"Reaftrmando su profunda adhesión a estas libertades fundamentales que constituyen las bases mismas de la justicia y de la paz en el mundo, y cuyo mantenimiento reposa esencialmente, de una parte, en un régimen político verdaderamente democrático, $y$, de otra, en una concepción y un respeto comunes de los derechos humanos que ellos invocan;

"Resueltos, en cuanto Gobiernos de Estados europeos animados de un mismo espiritu y en posesión de un patrimonio común de ideales y de tradiciones políticas, de respeto a la libertad y de preeminencia del Derecho, a tomar las primeras medidas adecuadas para asegurar la garantía colectiva de algunos de los derechos anunciados en ja Declaración Universal;

"Han convenido lo siguiente:"..

A continuación, el Convenio contiene el compromiso de las Altas Partes Contratantes de reconocer a toda persona dependiente de su jurisdicción el catálogo de derechos y libertades que se proclaman seguidamente (Tft. I: arts. $1^{\circ}$ al 18).

20 José Ortega y Gasset: "Introducción a una escimariva", en "Obres Completas", Alianza Edirocial, Madrid, 1979 (2a. reimpresión), vol. 6, pg. 315. 
El título II instituye la Comisión Europea de DD.HH. y el Tribunal Europeo de DD.HH., "con el fin de asegurar el respeto de los compromisos que resultan para las Altas Partes Contratantes del presente Convenio".

Las denuncias presentadas ante la Comisión pueden provenir de un Estado contratante, contra otro, por el incumplimiento de las disposiciones del Convenio (Art. 24). Puede también interponer demanda ante ella cualquier persona física, organización no gubernamental o grupo de particulares que se considere víctina de una violación por una de las Altas Partes contratantes, sólo en el caso que ésta haya declarado reconocer la competencia de la Conisión en esta materia (Art. 25.1). Al igual que en el Sistema Interanericano, la Comisión no puede conocer de un asunto sino después que se hayan agotado todos los recursos del derecho interno del reclamante (Art. 26).

En el caso del Tribunal Europeo, "sólo las Altas Partes Contratantes y la Comisión tienen facultad para someter un asunto al Tribunal" (Art. 44). Un asunto puede ser sometido al Tribunal sólo después que la Comisión haya comprobado el fracaso del arreglo amistoso (Art. 47).

Sería tarea larga, fatigosa e innecesaria reseñar aquí todos los instrumentos internacionales que encuentran su fundamento en la Carta de la ONU, en la Declaración Universal, en la Declaración Americana y en la Convención Europea de Derechos Humanos, los cuales conforman lo que se conoce como "Carta Internacional de Derechos Humanos".

Cabe señalar, sin embargo, que todos estos instrumentos se cimentan en la dignidad de la persona humana ${ }^{21}$, matriz y medida de todos sus derechos, a la cual el Prof. Pablo Lucas Verdú denomina supravalor; es decir, se fundan "en la persona en su dimensión axiológica ${ }^{22}$, para cuya plena realización ésta requiere la vigencia de los demás valores, como la igualdad, la justicia, la libertad y la paz.

\section{La Constitución de la Unión Europea (Proyecto de Tratado)}

Este proyecto colosal amerita aquí una referencia, no para describirio, sino que sólo para poner en relieve la energía de una voluntad política unificadora y el norte que orienta esta voluntad que en su base de lanzamiento sabe poner los valores compartidos de la cultura europea.

21 Se fundan en la dignidad humana el "Pacto Internacional de Derechos Eoonómicas, Sociales y Culturales" (N. Yark, 1966); el "Pacto Internacional de Derechor Civiles y Polf́ricos" (N+. York, 1976); la "Convención sobre ia abolición de la csclavitud, la trata de esclavos y las Instituciones y Prácticas análogas a la Esclavirad" (1956); la "Declaración sobre la Protección contra la Torturz y otros tratos o penas crueles, ishumanos o degradartes" (1975), y la Convención Intemacional sabre la misma materia de 1984: la "Declaración de los Derechos del Nifio" (1959); la "Declaración sobre la eliminación de las discriminaciones conura Ia Mujer" (1967); la "Convención lnternacional sobre represión y castigo del crimen del Apartheid" (1973); la "Carte Social Europea" (Torino, I 961); y el "Código de conducta para Funcionarios encargedos de hacer cumplir la $l<y^{n}$ (1979), entre muchos otros.

22 Pablo Lucas Vendý "Esrimativa y Polftica Constirucional", Fac. de Derecho, Universidad Complutense de Madrid, 1984, pgs. 122-123. 
Alguna vez recordamos que los países europeos han sufrido, sólo en el siglo pasado, dos cruentas guerras entre ellos; han padecido invasiones, el hambre, el miedo, la tortura y la muerte. $Y$, sin embargo, superando todos sus rencores recíprocos, derribando la Torre de Babel de sus idiomas, olvidando sus guerras religiosas y sus diferencias de sangre, de origen y de historia, caminan a pasos agigantados en pos del sueño de tantos visionarios como Ortega, como Churchill, como Schuman, como Monet, como De Gaulle, como Adenauer: La Unión Europea.

Sabemos que el Proyecto de Constitución Europa ha sufrido inevitables tropiezos que la Convención para el Futuro de Europa había sabido sortear con tesón y habilidad hasta mediados de diciembre de 2003, fecha en la cual, en la reunión de Bruselas, el Consejo Europeo le negó su aprobación por razones políticas o -de acuerdo al comentario de M. Giscard d'Estaing- más bien por la ausencia de política ${ }^{23}$.

No obstante lo cual, lo que nos interesa destacar es el hecho que -recogiendo los ideales que han engrandecido a Europa en su cultura y en su historia- el Proyecto de Constirución Europea se fundaba también en los valores de la cultura occidental.

Su Preámbulo, en lo pertinente, decía:

"Conscientes de que Europa es un continente portador de civilización, de que sus habitantes, llegados en ondas sucesivas desde los tiempos más remotos, han venido desarrollando los valores que sustenta el humanismo: la igualdad de las personas, la libertad y el respeto a la razón.

"Con inspiración en las herencias culturales, religiosas y humanistas de Europa, cuyos valores, todavía presentes en su patrimonio hicieron arraigar en la vida en sociedad el lugar primordjal de la persona y de sus derechos inviolables e inalienables, así como el respeto al Derecho.

"En el convencimiento de que la Europa, ahora reunida, avanzará por la senda de la civilización, del progreso y de la prosperidad en bien de todos sus habitantes, sin perjudicar a los más débiles y desfavorecidos; de que esa Europa quiere seguir siendo un continente abierto a la cultura, al saber y al progreso social; de que desea ahondar el carácter democrático y transparente de su vida pública y obrar en pro de la paz, la justicia y la solidaridad en el mundo.

23 Sobre ia Linión Europez y su Proyecto de Conscitución, ver: Luis Diez-Picazo: "La Conscitucionalización de Europa", Madrid, 1996 y “ ¿Una Constituctón sin declaración de derechos?", Rev. Espahola de Derecho Constiruciotra, No 32, 199 I; Eduardo Garcia de Enserria: "El Proyecto de Constituctón Europea", Rev. Española de Derecho Constitucional, No 45,1995; Franciseo Carreras. "Arálisis del Proyecto de Consricución Europea", Rev. de 1 Face. de Derecho Univ. Compiarense de Madrid, No 18, 1994; 1. Granado. "La Constiución Europea como problema juridico", en ha misma Revista y numero; Trevor Hartley. "The Foundacions of EEC Law", Oxford, Clarendon, 1998; Federico Mancini: "The Making of a Constitution for Europe". Common Market Law Review No 26, 1989; Peolo Mengozzi: "The Ruje of Law e il Dirirto Comunizario dei formaziones giurisprudenziale", Revista di Diritto Europeo No 3, 1993; Santiago Muñoz Machado: "La Unión Eturopea y las mutaciones del Estado", Alianza Edit, Madrid, 1993; A.C. Pereira Menaus, A. Bronfman, Cancele Outeda y C. Häkansson: "La Constitución Eurapea”, tratados consututivos y jurispradencia, Universidad de Santiago de Compostela 2000. 
"En la certeza de que los pueblos de Europa, sin dejar de sentirse orgullosos de su identidad y de su historia nacional, están resueltos a superar sus antiguas divistones y, cada vez más estrechamente unidos, a forjar un destino común,

"Con la seguridad de que, 'unida en la diversidad', Europa les brinda las mejores posibilidades de proseguir, respetando los derechos de todos y consciente de su responsabilidad ante las generaciones futuras de la tierra, la gran aventura que ha de ser un espacio especiaimente propicio para la esperanza humana,

"Reconocidos a los miembros de la Convención Europea por haber elaborado esta Constitución en nombre de los ciudadanos de los Estados de Europa, (...)"

Su Art. I-1.2 establecía que "La Unión está abierta a todos los Estados europeos que respeten sus valores y se comprometan a promoverlos en común".

Su Art. I-2, que se titula precisamente "Valores de La Unión", decía:

"La Unión se fundamenta en los valores de respeto a la dignidad humana, libertad, democracia, igualdad, Estado de Derecho y respeto a los derechos humanos. Estos vajores son comunes a los Estados miembros en una sociedad caracterizada por el pluralismo, la tolerancia, la justicia, la solidaridad y la no discriminación."

Su Art. I-3, referido a los "Objetivos de la Unión", prescribfa:

"1. La finalidad de la Unión es promover la paz, sus valores y el bienestar de sus pueblos.

"2. La Unión ofrecerá a sus ciudadanos un espacio de libertad, seguridad y justicia sin fronteras interiores y un mercado único en que la competencia sea libre y honesta.

“3. La Unión obrará en pro del desarrollo sustentable de Europa basado en un crecimiento económico equilibrado, en una economla social de mercado altamente competitiva, tendiente al pieno empleo y al progreso social, en un nive! elevado de protección y mejoría de la calidad del medio ambiente. Asimismo, promoverá el progreso cientifico y técnico.

"La Unión combatirá la marginación social y la discriminación y fomentará la justicia y la protección sociales, la igualdad entre mujeres y hombres, la solidaridad entre las generaciones y la protección de los derechos del niño.

"La Unión fomentará la cohesión económica, social y territorial y la solidaridad entre los Estados miembros.

"La Unión respetará la riqueza de su diversidad cultural y lingüística y velará por la preservación y el desarrollo del patrimonio cultural europeo.

"4. En sus relaciones con el resto del mundo, la Unión afirmará y promoverá sus valores e intereses. Contribuirá a la paz, a la seguridad, à desarrollo susten- 
table del planeta, a la solidaridad y al respeto mutuo entre los pueblos, al comercio libre y equitativo, a la erradicación de la pobreza y a la protección de los derechos humanos, especialmente los derechos del niño, a la estricta observancia y al desarrollo del derecho internacional y, en particular, al respeto de los principios de la Carta de las Naciones Unidas.

"5. Estos objetivos se perseguirán por los medios apropiados, de acuerdo con las competencias atribuidas a la Unión en la Constitución" ${ }^{24}$

\section{El Cimiento Valórico de las Constituciones Modernas}

Resulta alentador comprobar cómo, aun desde mucho antes de la Declaración Universal de Derechos Humanos, dos Constituciones americanas contenían valores similares; y cómo, con posterioridad a dicha Declaración, el Derecho Internacional de los Derechos Humanos y los valores jurídicos en que éste se funda, han impregnado profundamente a las Constituciones Políticas posteriores a la Segunda Guerra Mundial.

Con todo, iniciaremos esta revista con las Cartas Fundamentales europeas, por ser ellas las primeras que instituyeron un nuevo modo de situar a la persona humana como centro de gravedad del universo jurídico, en lugar del Estado, como ocurría anteriormente.

\section{Constituciones Europeas}

\section{Ley Fundamental (Grundgesetz) de la República Federal de Alemania (1949)}

Esta Carta tiene el mérito de haber sido la primera en modificar la estructura tradicional de las Constituciones dedicando su Capítulo I a la parte dogmática ("Derechos Fundamentales") y a los valores encarnados en el pueblo alemán que expresa su Código Político. Tiene, además, el mérito de haber hecho directamente vinculantes para todos los poderes -sin necesidad de reglas de desarrollo- las normas que declaran y garantizan los derechos fundamentales.

Su artículo $1^{\circ}$ dice así:

"1. La dignidad del hombre es sagrada y su respeto y protección constituyen un deber de todas las autoridades del Estado.

“2. El pueblo alemán reconoce, en consecuencia, los derechos inviolables e inalienables del hombre como fundamento de toda comunidad humana, de la paz y de la justicia en el mundo.

“3. Los derechos fundamentales que se definen a continuación vinculan al Poder Legislativo, al Poder Ejecutivo y a los Tribunales como derecho directamente aplicable".

24 Ver: "Proxecto de Tratado Polo que se Instituie whha Constitucion para Europa", Edición comentada, con Prólogo de Manuel Fraga lribarne (adoptado por consenso por la Convención Europea entre el 13-VI al 10-VIl-2003), Edic. Fundación Galicia Europa, Santiago de Compostela, 2003, gentilmente facilitado por el Prof. Alan Bronfman. 
En esta misma orientación garantista, el art. 19.2 prescribe "En ningún caso un derecho fundamental podrá ser afectado en su esencia”. Y el art. 19.4, consagrando la tutela judicial de los derechos, señala: "Toda persona cuyos derechos sean violados por el poder público, podrá recurrir a la via judicial (...)".

\section{Constitución de la República de Italia (1947)}

Su art. $3^{\circ}$ prescribe:

"Todos los ciudadanos tienen la misma dignidad social y son iguales ante la ley, sin distinción de sexo, raza, lengua, religión, opiniones políticas ni circunstancias personales y sociales.

“Constituye obligación de la República suprimir los obstáculos de orden económico y social que, linitando de hecho la libertad y la igualdad de los ciudadanos, impiden el pleno desarrollo de la persona humana y la participación efectiva de todos los trabajadores en la organización politica, económica y social del pais".

Esta última disposición ha servido de base para establecer el deber del Estado de promoción de la igualdad y de otros derechos fundamentales ${ }^{25}$.

Su art. 11 declara:

"Italia repudia la guerra como instrumento de ataque a la libertad de los demás pueblos, y como medio de solución de las controversias internacionales; accede, en condiciones de igualdad con los dernás Estados, a las limitaciones de soberanía necesarias para un ordenamiento que asegure la paz y la justicia entre las naciones, y promoverá $y$ favorecerá las organizaciones internacionales encaminadas a este fin".

\section{Constitución de la República Francesa (1958)}

Dice su Preámbulo, en lo pertinente a la materia en estudio:

"El pueblo francés proclama solemnemente su adhẹsión a los Derechos del Hombre y a los principios de soberanía nacional tal como fueton definidos en la Declaración de 1789, confirmada y completada por el Preámbulo de la Constitución de 1946.

"En virtud de estos principios y del de libre determinación de los pueblos, la República ofrece a los territorios de Ultramar que manifiesten la voluntad de adherirse a ellos unas instituciones nuevas basadas en el ideal común de libertad, igualdad y fraternidad y concebidas con vistas a la evolución democrática de todos ellos".

25 Ver arss. 9.2. de la Constitución española y el art. $5^{\circ}$ inc. $2^{\circ}$ de la de Chile. 
El Preámbulo de la célebre Declaración de 1789, señala:

"Los representantes del pueblo francés, constituidos en Asamblea Nacional, considerando que la ignorancia, el olvido o el desprecio de los derechos del hombre son las únicas causas de los males públicos y de la corrupción de los gobiernos, han resuelto exponer en una declaración solemne los derechos naturales, inalienables y sagrados del hombre a fin de que esta declaración, estando constantemente presente en todos los miembros del cuerpo social, les recuerde sin cesar sus derechos y sus deberes; a fin de que los actos del Poder Legislativo y los del Poder Ejecutivo, al poder ser comparados en cada instante con el fin de toda institución política, sean más respetados; a fin de que las reclamaciones de los ciudadanos fundadas desde ahora sobre principios simples e indudables, se dirijan siempre al mantenimiento de la Constitución y al bienestar de todos".

Luego, su Art. $1^{\circ}$ contiene la clásica declaración:

"Los hombres nacen y permanecen libres e iguales en derechos".

\section{Constitución de la República de Turquia (1961)}

Su Preámbulo, en lo que nos atañe, dice:

"La Nación Turca que, a lo largo de su historia, ha vivido en la independencia $y$ ha luchado por sus derechos y libertades (...)

"Con el fin de fundar un Estado democrático de Derecho con todos los fundamentos jurídicos y sociales capaces de realizar y de garantizar los derechos y libertades del hombre, la solidaridad nacional, la justicia social, la paz y la conveniencia del individuo y de la sociedad;

"Ha aprobado esta Constitución (...) y la confia al cuidado vigilante de sus hijos imbuidos de libertad, de justicia y de virtud, con la convicción de que su verdadera garantía está en la conciencia y la voluntad de los ciudadanos".

Su art. $2^{\circ}$ declara:

"La República Turca es un Estado nacionalista, democrático, laico y social, que se rige por el imperio de la ley, y se basa en los derechos del hombre y en los principios fundamentales que se enuncian en el Preámbulo".

Su Art. 14, inciso final, prescribe:

"No se podrán infligir castigos incompatibles con la dignidad bumana". 


\section{Constitución de Grecia (1975)}

Su Art. $2^{\circ}$ dice:

"1. El respeto y la protección del valor de la persona humana constituyen obligación primordial del Estado.

"2. Grecia persigue, ateniéndose a las reglas universalmente reconocidas del derecho internacional, la consolidación de la paz y de la justicia así como el desarrollo de relaciones amistosas entre los pueblos y los Estados".

\section{Constitución de la República de Portugal (1976)}

Esta Constitución se inicia con un capitulo denominado "Principios Fundamentales". Su Art. $1^{0}$ prescribe:

"Portugal es una república soberana, basada en la dignidad de la persona humana y en la voluntad popular y empeñada en la construcción de una sociedad libre, justa y solidaria".

Su Art. 13.1 declara que "Todos los ciudadanos tendrán la misma dignidad social y serán iguales ante la ly".

Su Art. 16 señala que "Los preceptos constitucionales y legales relativos a los derechos fundamentales deberán ser interpretados e integrados en armonía con la Declaración Universal de los Derechos del Hombre".

\section{Constitución Política de España (1978)}

Esta Constitución tiene el mérito de propugnar ciertos valores superiores que especifica en su articulado, de tal manera que ella contiene valores positivados, los cuales -sin perjuicio de su rango constitucional - no agotan la virtualidad propia de estos valores como tales, sirviendo las funciones normativas, interpretativas e integradoras inherentes a ellos.

Su Preámbulo declara:

"La Nación española, deseando establecer la justicia, la libertad y la seguridad y promover el bien de curantos la integran, en uso de su soberanía, proclama su voluntad de:

"Garantizar la convivencia democtática dentro de la Constitución y de las leyes conforme a un orden económico y social justo.

"Consolidar un Estado de Derecho que asegure el imperio de la ley como expresión de la voluntad popular.

"Proteger a todos los españoles y puebios de España en el ejercicio de los derechos humanos, sus culturas y tradiciones, lenguas e instituciones. 
"Promover el progreso de la cultura y de la economía para asegurar a todos una digna calidad de vida.

“Establecer una sociedad democratica avanzada, y

"Colaborar en el fortalecimiento de unas relaciones pacíficas y de eficaz cooperación entre todos los pueblos de la Tierra."

Su Art. $1^{\circ}$ prescribe:

"1. España se constituye en un Estado social y democrático de Derecho, que propugna como valores superiores de su ordenamiento jurídico la libertad, la justicia, la igualdad y el pluralismo político".

Su Art. 9.2 dice:

"Corresponde a los poderes públicos promover las condiciones para que la libertad y la igualdad del individuo y de los grupos en que se integra sean reales y efectivas; remover los obstáculos que impidan o dificulten su plenitud y facilitar la participación de todos los ciudadanos en la vida polf́tica, económica, cultural y social".

Su Art. 10 prescribe:

"1. La dignidad de la persona, los derechos inviolables que le son inherentes, el libre desarrollo de la personalidad, el respeto a la ley y a los derechos de los demás son fundarnento del orden político y de la paz social.

"2. Las normas relativas a los derechos fundamentales y a las libertades que la Constitución reconoce se interpretarán de conformidad con la Declaración Universal de Derechos Humanos y los tratados y acuerdos internacionales sobre las mismas materias ratificados por España".

\section{Constitución de Rumania (1991)}

Es admirable constatar cómo países que estuvieron dominados bajo la hegemonía de la Unión Soviética y sometidos -en sus principios y en sus fines-a la ideología marxista-ieninista, en que tanto la vida pública como la privada estuvieron controladas por el Estado a través de los respectivos partidos comunistas, con posterioridad al término de aquella dominación recuperaron plenamente su identidad original y hoy comparten los mismos principios y valores de la cultura occidental. Examinaremos aquf́ las Constituciones de Rumania, de la República Checa, de la República de Eslovaquia, de la Federación Rusa y de Polonia, las que denotan esta nueva orientación axiológica. En su Art. 1.3, ubicado entre los "Principios Generales", la Carta Magna de Rumania prescribe: 
"Rumania es un Estado de derecho, democrático y social, en el cual la dignidad del ser humano, los derechos y las libertades de los ciudadanos, el libre desarrollo de la personalidad humana, la justicia y el pluralismo político representan valores supremos y se garantizan".

Su Art. 20.1 dispone que "Las disposiciones constitucionales relativas a los derechos y a las libertades de los ciudadanos se interpretarán y aplicarán de conformidad con la Declaración Universal de Derechos Humanos, los Convenios y los demás Tratados de los cuales Rumania es parte".

\section{Constitución de la República Checa (1992)}

El Preámbulo de esta Carta, en lo pertinente, declara:

"Nosotros, los ciudadanos de la República Checa en Bohemia, Moravia y Silesia, al tiempo de la renovación de un Estado checo independiente, fiel a todas las apreciables tradiciones de nuestra antigua fisonomia estatal (...) han resuelto construir, proteger y desarrollar la República Checa en el espíritu de los inviolables valores de la dignidad humana y la libertad,

"- como el hogar de ciudadanos iguales y libres, quienes están conscientes de sus deberes hacia los otros y de su responsabilidad hacia todos,

" - cotno un Estado libre y democrático basado en el respeto por los derechos humanos y los principios de la sociedad civilizada,

" como parte de la familia de la democracia europea y mundial,

" - han resuelto proteger y desarrollar conjuntamente la herencia natural y cultural y la riqueza material y espiritual,

"- han resuelto someterse totalmente a los principios probados con el tiempo de un Estado de derecho observante de la ley (...)

Su Art. $1^{\circ}$ dispone:

"La República Checa es un Estado de derecho soberano, unificado y democrático, basado en el respeto a los derechos y libertades del individuo y de los ciudadanos."

Su Art. $3^{\circ}$ prescribe que "Parte del orden constitucional de la República Checa es La Carta de Derechos Fundamentales y Libertades".

Por su parte, la Carta referida dispone en su Art. 10:

"Todas las personas son libres e iguales en su dignidad y en sus derechos. Sus derechos fundamentales y libertades son inherentes, inalienables, no limitables $e$ inderogables".

Su Art. 2.I. prescribe: "Que el Estado está fundado en los valores democráticos y no debe estar comprometido con una ideología exclusiva o con una religión en particular." 


\section{Constitución de la República Eslovaca (1992)}

En lo pertinente en su Preámbulo, declara que:

"Intentando implementar una forma democrática de gobierno para garantizar una vida de libertad, y promover el cultivo del espíritu y la prosperidad económica $(. .)^{n}$.

Su Art. 1.1. prescribe: "La República Eslovaca es un Estado soberano, democrático y gobernado por la regla de la ley. No está comprometido con ninguna ideologia o religión."

Su Arr. 12.1. declara:

"Todos los seres humanos son libres e iguales en dignidad y en derechos. Sus derechos fundamentales y libertades están consagrados, son inalienabies, imprescriptibles e irreversibles."

\section{Constitución de la Federación Rusa (1993)}

En su Cap. L, titulado "Bases del Régimen Constitucional", su Art. $2^{\circ}$ prescribe:

"El Individuo, sus Derechos y Libertades, son valores excelsos. El reconocimiento, resguardo y defensa de las libertades y derechos humanos y cívicos son obligación del Estado."

Su Art. 7.1. declara: "La Federación Rusa es un Estado social cuya politica está dirigida a crear las condiciones que garanticen una vida digna y el libre desarrollo del individuo."

Su Art. 17 ubicado en el Cap. titulado "Derechos y Libertades del Ser Humano y del Cüudadano", señala:

"1. En la Federación Rusa se reconocen y se garantizan los derechos y las libertades del ser hurnano y del ciudadano de acuerdo con los principios y las normas del Derecho Internacional y en concordancia con la presente Constitución.

"2. Los derechos y las libertades fundamentales del ser humano son inalienables y pertenecen a cada persona desde su nacimiento".

El Art. 21, en el mismo Capítulo, establece:

"1. La dignidad del individuo está defendida por el Estado. No puede existir ningún fundamento para menospreciarla.

"2. Nadie puede ser objeto de torturas, violencia u otro tipo de trato que sea rígido así como de castigos que menoscaben la dignidad humana (...)

El Art. 44.2.2. prescribe: "Toda persona tiene derecho a participar en las actividades culturales y a hacer uso de las instituciones de la cultura, y al acceso a los valores culturales". 


\section{Constitución de la República de Suecia (Ley de Reforma de 24-XI-1994)}

Su Art. $2^{\mathrm{a}}$ prescribe:

"El poder público se ejercerá con el debido respeto al igual valor de todos y a la libertad y dignidad del individuo.

"El bienestar personal, económico y cultural del individuo constituye el objeto fundamental de los poderes públicos, a los cuales corresponderá en particular asegurar el derecho al trabajo, a la vivienda y a la educación, así como promover la asistencia y seguridad social y un buen ambiente de vida".

\section{Constitución de la República de Polonia (1997)}

Su Preárnbulo, en lo pertinente, declara:

"Nosotros, la nación polaca -todos los ciudadanos de la República-

"- tanto aquéélios que creen en Dios,

"- fuente de la verdad, de la justicia, de la bondad y de la belleza,

"- así como aquéllos que no participan de esta fe

" $-y$ que fundan sus valores universales en otras fuentes,

“- iguales en derechos y ел deberes hacia Polonia que es nuestro bien común,

“- reconociendo a nuestros ancestros por su trabajo, por su lucha por la independencia plagada de inmensos sacrificios, teniendo la cultura sus raíces en la herencia cristiana de la nación y en los valores humanos universales, (...)

"- conscientes de la necesidad de cooperar con todos los países para el bien de la Familia humana,

" - teniendo en la memoria las dolorosas pruebas sufridas en la época en que las libertades y los derechos fundamentales del hombre eran violados en nuestra Patria (...)

“- instituimos la Constitución de la República de Polonia en el carácter de derecho fundamental del Estado,

“- fundado en el respeto de la libertad y de la justicia, la cooperación entre las autoridades, el diálogo social y el principio de subsidiariedad reforzando los derechos de los ciudadanos y de sus colectividades.

"A todos aquellos que, para el bien de la Tercera República, aplicarán las disposiciones de la Constitución,

“- hacemos el llamado para que las apliquen en el respeto de la dignidad propia de la naturaleza del bombre, de su derecho a la libertad y su deber de solidaridad con los demás, 
" - y que el respeto de estos principios sea para ellos el fundamento inquebrantable de la República de Polonia".

Su Art. $1^{\circ}$ señala que: "La Repríblica de Polonia es el bien común de todos los ciudadanos." Su Art. $2^{\circ}$ prescribe que: "La República de Polonia es un Estado democrático de derecho que pone en práctica los principios de la justicia social."

Su Art. 30 ubicado en el 'Título II: "Las Libertades, los Derechos y los Deberes del Hombre y del Ciudadano", establece:

"La dignidad inherente $\mathrm{e}$ inalienable del hombre constituye la fuente de las libertades y de los derechos del hombre y del ciudadano. Ella es inviolable y su respeto y protección son el deber de los poderes públicos".

\section{Constituciones Americanas}

Pasaremos revista a aquéllas que invocan o se fundan en valores, siguiendo el orden de su antigüedad.

\section{La Constitución de los Estados Unidos de Norteamérica (1787)}

No obstante tratarse de una Constitución originada en el siglo XVIII, la incluimos aquf por encontrarse vigente, tanto en su normativa como en su espíritu; por haberse renovado permanentemente por la via jurisprudencial; y por ser, talvez, la primera Constitución de base axiológica, tanto más si se considera su antecedente, la Declaración de Derechos de Virginia del 12 de junio de 1776.

La Declaración sostiene:

"I. Que todos los hombres son, por naturaleza, igualmente libres e independientes, y que tienen ciertos derechos inherentes de los que no pueden privar o desposeer a su posteridad por ninguna especie de contrato cuando se incorporan a la sociedad; a saber, el goce de la vida y de la libertad con los medios de adquirir y poseer la propiedad y perseguir y obtener la felicidad y la seguridad."

Por su parte, el Preámbulo de la Constitución de este gran país declara:

"Nosotros, el pueblo de los Estados Unidos, con el propósito de formar una Unión más perfecta, establecer la justicia, garantizar la Tranquilidad interior, atender a la Defensa común, fomentar el Bienestar general, y asegurar las bendiciones de la Libertad para nosotros y nuestra Posteridad, establecemos y sancionamos esta Constitución para los Estados Unidos de América" ${ }^{26}$ 


\section{Constitución de la Nación Argentina (1853)}

También esta Carta, la más antigua de Iberoamérica, ostenta en su Preámbulo una justificación valórica. Lo más notable es que su reforma de 1994 (Boletín Oficial del 23-VIII-94), al ororgar jerarquía constitucional a la Declaración Americana de los Derechos y Deberes del Hombre, a la Declaración Universal de Derechos Humanos y a otros instrumentos internacionales basados en aquéllas, al adoptarlos y al declararlos complementarios de los derechos y garantías reconocidos en la Constitución, adquiere y enriquece su contenido con toda la fundamentación axiológica que poseen aquellos principios y normas del Derecho lnternacional de los Derechos Hurnanos, convirtiéndose así en la Carta Política más avanzada en esta materia.

El antiguo Preámbulo dice así:

"Nos, los representantes del pueblo de la Nación Argentina, teunidos en Congreso General Constituyente por voluntad y elección de las provincias que la componen, en cumplimiento de pactos preexistentes, con el objeto de constituir la unión nacional, afianzar la justicia, consolidar la paz interior, proveer la defensa común, promover el bienestar general, y asegurar los beneficios de la libertad, para nosotros, para nuestra posteridad, y para todos los hombres del mundo que quieran habitar en el suelo argentino: invocando la protección de Dios, fuente de toda razón y justicia: ordenamos, decretamos y establecemos esta Constitución, para la Nación Argentina".

La disposición introducida por la Reforma de 1994 al art. 75 No 22 de la Constitución, teza así:

"La Declaración Americana de los Derechos y Deberes del Hombre; la Declaración Universal de Detechos Humanos; la Convención Americana sobre Derechos Humanos; el Pacto Internacional de Derechos Económicos, Sociales y Culturales; el Pacto Internacional de Derechos Civiles y Políticos y su Protocolo Facultativo; la Convención sobre la Prevención y la Sanción del Delito de Genocidio; la Convención Internacional sobre la Eliminación de todas las Formas de Discriminación Racial; la Convención sobre la Eliminación de todas las Formas de Discriminación sobre la Mujer; la Convención contra la Tortura y otros Tratos o Penas Crueles, Inhumanos o Degradantes; ta Convención sobre los Derechos del Niño; en las condiciones de su vigencia, tienen jerarquía constitucional, no derogan artículo alguno de la primera parte de esta Constitución y deben entenderse complementarios de los derechos y garantías por ella reconocidos. Sólo podrán ser denunciados, en su caso, por el Poder Ejecutivo nacional, previa aprobación de las dos terceras partes de la totalidad de los miembros de cada Cámara". 


\section{Constitución del Estado Libre Asociado de Puerto Rico (1952)}

El Preámbulo, en la parte pertinente, declara:

"Que consideramos factores determinantes en nuestra vida ... el afán por la educación, la fe en la justicia, la devoción por la vida esforzada, laboriosa y pacífica, la fidelidad a los valores del ser humano por encima de posiciones sociales, diferencias raciales e intereses económicos, y la esperanza de un mundo mejor basado en estos principios".

Su art. $2^{\circ}$ contiene la Carta de Derechos y su Secc. I dice así:

"La dignidad del ser humano es inviolable. Todos los hombres son iguales ante la ley. No podrá establecerse discriminación alguna por motivo de raza, color, sexo, nacimiento, origen o condición social, ni ideas políticas o religiosas. Tanto las leyes como el sistema de instrucción pública encarnarán estos principios de esencial igualdad humana".

\section{Constitución Politica de la República de Venezuela (1961)}

Su Preámbulo, en la parte atinente al tema, dice así:

"El Congreso de la República de Venezuela... en representación del pueblo venezolano, para quien invoca la protección de Dios Todopodoroso;

"con el propósito de mantener la independencia y la integridad territorial de la Nación, fortalecer su unidad, asegurar la libertad, la paz y la estabilidad de las instituciones;

"proteger y enaltecer el trabajo, amparar la dignidad humana promover el bienestar general y la seguridad social; lograr la participación equitativa de todos en el disfrute de la riqueza, según los principios de la justicia social y fomentar el desarrollo de la economía al servicio del hombre, mantener la igualdad social y jurídica, sin discriminación derivada de raza, sexo, credo o condición sociał"

\section{Constitución Polltica del Estado de Bolivia (1967)}

Su art. $6^{\circ}$ dice asi:

"I. Todo ser humano tiene personalidad y capacidad jurídicas, con arreglo a las leyes. Goza de los derechos, libertades y garantías reconocidas por esta Constitución, sin distinción de raza, sexo, idioma, religión, opinión política o de otra indole, origen, condición económica o social, u otra cualquiera.

"II. La dignidad y la libertad de la persona son inviolables. Respetarlas y protegerlas es deber primordial del Estado". 


\section{Constitución Politica de la República de Panamá (1972)}

Su Preámbulo dice así:

"Con el fin supremo de fortalecer la Nación, garantizar la libertad, asegurar la democracia y la estabilidad institucional, exaltar la dignidad humana, promover la justicia social, el bienestar general y la integración regional, $e$ invocando la protección de Dios, decretamos la Constitución Politica de Panamá".

\section{Constitución Politica de la República de Ecuador (1979)}

Su Preámbulo declara:

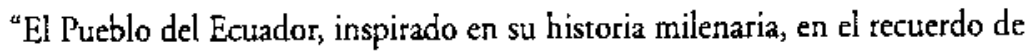
sus héroes y en el trabajo de hombres y mujeres que, con su sacrificio, forjaron la patria; frel a los ideales de libertad, igualdad, justicia, progreso, solidaridad, equidad y paz que han guiado sus pasos desde los albores de la vida republicana, proclama su voluntad de consolidar la unidad de la nación ecuatoriana en el reconocimiento de la diversidad de sus regiones, pueblos, etnias y culturas, invoca la protección de Dios, y en ejercicio de su soberanía, establece en esta Constitución las normas fundamentales que amparan los derechos y libertades, organizan el Estado y las instituciones democtáticas e impulsan el desarrollo económico y social".

\section{Constitución Politica de la República de Chile (1980)}

Esta Constitución contiene, en su Capítulo I, las "Bases de la Institucionalidad" que permean todos sus demás capítulos y poseen una rigidez reforzada para el caso de intentarse su reforma. En su articulo $1^{\circ}$ proclama la libertad, la igualdad y la dignidad humana y pone al Estado al servicio de la persona; señala como finalidad el bien común dirigido a procurar a cada miembro de la comunidad la mayor realización espiritual y material que sea posible e impone al Estado deberes precisos respecto de la familia y de la comunidad nacional, con especial referencia a las asociaciones intermedias entre la persona y el Estado. Además de los valores asegurados en su art. $1^{\circ}$, el art. $5^{\circ}$ inc. $2^{\circ}$ impone como limitación al ejercicio de la soberanía, el respeto a los derechos fundamentales $y$, como deber de los órganos del Estado, respetar y promover los derechos garantizados en la Carta, así como por los tratados internacionales.

Los textos respectivos rezan ast:

"Art. $1^{\circ}$ Las personas nacen libres e iguales en dignidad y derechos.

"La familia es el núcleo fundamental de la sociedad.

"El Estado reconoce y ampara a los grupos intermedios a través de los cuales se organiza y estructura la sociedad y les garantiza la adecuada autonomía para cumplir sus propios fines especificos. 
"El Estado está al servicio de la persona humana y su finalidad es promover el bien común, para lo cual debe contribuir a ctear las condiciones sociales que permitan a todos y a cada uno de los integrantes de la comunidad nacional su mayor realización espiritual y material posible, con pleno respeto a los derechos y garantías que esta Constitución establece.

"Es deber del Estado resguardar la seguridad nacional, dar protección a la población y a la familia, propender al fortalecimiento de ésta, promover la integración armónica de todos los sectores de la Nación y asegurar el derecho de las personas a participar con igualdad de oportunidades en la vida nacional".

"Art. 5o, inc. 20: "El ejercicio de la soberanía reconoce como limitación el respeto a los derechos esenciales que emanan de la naturaleza humana. Es deber de los órganos del Estado respetar y promover tales derechos, garantizados por esta Constitución, así como por los tratados internacionales ratificados por Chile y que se encuentren vigentes".

Su art. 22 inciso $2^{\circ}$, prescribe que "Los chilenos tienen el deber fundamental (...) de contribuir a preservar la seguridad nacional y los valores esenciales de la tradición chilena".

\section{Constitución de La República de El Salvador (1983)}

Su Preámbulo dice asi:

"Nosotros, representantes del pueblo salvadoreño reunidos en Asamblea Constituyente, puesta nuestra confianza en Dios, nuestra voluntad en los altos destinos de la Patria y en ejercicio de la potestad soberana que el pueblo de El Salvador nos ha conferido, animados del ferviente deseo de establecer los fundamentos de la convivencia nacional con base en el respeto a la dignidad de la persona humana, en la construcción de una sociedad más justa, esencia de la democracia, y al espiritu de libertad y justicia, valores de nuestra herencia humanista."

Su Art. $1^{\circ}$ prescribe:

"El Salvador reconoce a la persona humana como el origen y el fin de la actividad del Estado, que está organizado para la consecución de la justicia, de la seguridad jurídica y del bien común.

"En consecuencia, es obligación del Estado asegurar a los habitantes de la República, el goce de la libertad, la salud, la cultura, el bienestar económico y la justicia social".

\section{Constitución Política de la República de Guatemala (1985)}

Su Título I está dedicado a "La Persona Humana, Fines y Deberes del Estado". Contiene un Capítulo Único, con dos artículos, que dicen: 
"Art. 10. Protección a la Persona. El Estado de Guatemala se organiza para proteger a la persona y a la familia, su fin supremo es la realización del bien común”.

"Art. 20. Deberes del Estado. Es deber del Estado garantizarles a los habitantes de la República la vida, la libertad, la justicia, la seguridad, la paz y el desarrollo integral de la persona".

\section{Constitución Politica de la República de Nicaragua (1987)}

El Art. $5^{\circ}$ de esta Carta, ubicado en el Tírulo I que contiene los "Principios Fundamentales", declara, en su inciso primeto:

"Son principios de la nación nicaragüense: la libertad; la justicia, el respeto a la dignidad de la persona humana; el pluralismo político, social y étnico; el reconocimiento a las distintas formas de propiedad; la libre cooperación internacional; y el respeto a la libre autodeterminación de los pueblos".

El inciso $6^{\circ}$ del mismo artículo prescribe:

"Nicaragua se adhiere a los principios que conforman el Derecho Internacional Americano reconocido y ratificado soberanamente".

\section{Constitución de la República Federal de Brasil (1988)}

Su Preámbulo declara:

"Nosotros, representantes del pueblo brasileño, reunidos en Asamblea Nacional Constituyente para instituir un Estado democrático, destinado a asegurar el ejercicio de los derechos sociales e individuales, la libertad, la seguridad, el bienestar, el desarrollo, la igualdad y la justicia como valores supremos de una sociedad fraterna, pluralista y sin prejuicios, fundada en la armonia social y comprometida, en el orden interno e internacional, con la solución pacífica de las controversias, pronulgamos, bajo la protección de Dios, la siguiente Constitución de la República Federal de Brasil”.

Su art. $1^{\circ}$, ubicado en el Ti. I que contiene los "Principios Fundamentales", prescribe que "La República Federal de Brasil (...) se constintye como Estado democrático de Derecho y tiene como fundamentos: III. la dignidad de la persona humana; IV. los valores sociales del trabajo y de la libre iniciativa; V. el plutalismo político".

\section{Constitución Política de Colombia (1991)}

Su Preámbulo expresa:

"El Pueblo de Colombia, en ejercicio de su poder soberano representado por sus delegatarios a la Asamblea Nacional Constituyente, invocando la protec- 
ción de Dios, y con el fin de fortaiecer la unidad de la nación y asegurar a sus integrantes la vida, la convivencia, el trabajo, la justicia, la igualdad, el conocimiento, la libertad y la paz, dentro de un marco jurídico democrático y participativo que garantice un orden político, económico y social justo, y comprometido a impulsar la integración de la comunidad latinoamericana, decreta, sanciona y promulga la siguiente Constitución".

Su Art. 10, que también trata "De los Principios Fundamentales" declara:

"Colombia es un Estado social de derecho, organizado en forma de República unitaria, descentralizada, con autonomía de sus entidades territoriales, democrática, participativa y pluralista, fundada en el respeto de la dignidad humana, en el trabajo $y$ la solidaridad de las personas que la integran y en la prevalencia del interés general".

\section{Constitución de la República de Paraguay (1992)}

Su Preámbulo declara:

"EJ pueblo paraguayo, por medio de sus legítimos representates reunidos en Convención Nacional Constituyente, invocando a Dios, teconociendo la dignidad humana, con el fin de asegurar la libertad, la igualdad y la justicia, reafirmando los principios de la democracia republicana, representativa, participativa y pluralista, ratificando la soberanfa e independencia nacionales, e integrado a la comunidad internacional, sanciona y promulga esta Constitución".

Acogiendo un principio originado en el Derecho Internacional de los DD.HH., el de discriminación positiva, destinado a ternover las desigualdades existentes, su Art. 46 prescribe:

"De la igualdad de las personas.- Todos los habitantes de la República son iguales en dignidad y derechos. No se admiten discriminaciones. El Estado removerá los obstáculos e impedirá los factores que las mantengan o las propicien.

"Las protecciones que se establezcan sobre desigualdades injustas no serán consideradas como factores discriminatorios sino igualitarios".

\section{Constitución Politica del Perú (1993)}

Su Título I trata "De la Persona y de la Sociedad".

Su Art. $1^{0}$-situado en el Capítulo que contiene los "Derechos Fundamentales de la Persona"- prescribe:

"La defensa de la persona humana y el respeto de su dignidad son el fin supremo de la sociedad y del Estado". 
A continuación del art. $2^{\circ}$, que establece el catálogo de los derechos fundamentales, el art. $3^{\circ}$ señala:

"La enumeración de los derechos establecidos en este capítulo no excluye los demás que la Constitución garantiza, ni otros de naturaleza análoga o que se fundar en la dignidad del hombre, o en los principios de soberanía del pueblo, del Estado democrático de derecho y de la forma republicana de gobierno".

\section{Otras Constituciones}

Al desarrollar esta investigación hemos quedado sorprendidos al descubrir que países del continente Asiático o de África y del Medio Oriente, que no se nutrieron de los valores de la cultura occidental, hoy en día comparten, sin embargo, nuestros valores y así lo declaran en sus instrumentos constitucionales. Pasaremos breve revista a las Cartas de Japón, Sud Africa e Israel.

\section{Constitución de Japón (1946)}

\section{Su Preámbulo dice así:}

"Nosotros, el pueblo japonés, (...) decididos a garantizar para nosotros mismos y nuestra posteridad los frutos de la cooperación paćfica con todas las naciones y los beneficios de la libertad en todo este pais, y resueltos a no volver a sufrir nunca más los horrores de la guerra a causa de las acciones del gobietno, proclamamos que el poder soberano reside en el pueblo y promulgamos con toda firmeza la presente Constitución. La tarea de gobernar es un derecho sagrado del pueblo, de quien dimana la autoridad para ejercerla, y son los representantes del pueblo quienes tienen poder para llevarla a cabo, a fin de que sea el pueblo el que disfrute de sus beneficios. En este principio, que es universal para la humanidad, se basa la presente Constitución (...).

"Nosotros, el pueblo japonés, deseamos la paz en todo tiempa y somos profundamente conscientes de los elevados ideales que rigen las relaciones humanas, y estamos decididos a preservar nuestra seguridad y nuestra existencia, confiando en la justicia y en las creencias de los pueblos del mundo anantes de la paz. Desearnos ocupar un lugar honroso en una sociedad internacional que luche por conservar la paz y porque desaparezcan para siempre de la faz de la tierra la tiranía y la esclavitud, la opresión y la intolerencia (...).

"Creemos que ninguna nación es responsable sólo ante sí misma, puesto que las normas de moralidad polftica son universales; y que el acatamiento de tales normas es un deber de todas las naciones que deseen conservar su propia soberanía y justificar sus relaciones soberanas con las dernás naciones.

"Nosotros, el pueblo japonés, empefiamos nuestro honor nacional en el cumplimiento de estos elevados propósitos e ideales por todos los medios a nuestro alcance." 


\section{Constitución de la República de Sud Africa (1996)}

Su Preámbulo dice:

"Nosotros, el pueblo de Sud África, reconociendo las injusticias de nuestro pasado; haciendo honor a todos quienes sufrieron por la justicia y la libertad en nuestra tierra; con respeto por todos aquellos que han trabajado para construir y desarrollar nuestro país; y en la creencia que Sud África pertenece a todos quienes viven en ella, unidos en nuestra diversidad (...)

"... Adoptamos esta Constitución como la suprema ley de la república con el propósito de:

"Cicatrizar las divisiones del pasado y establecer una sociedad basada en los valores democráticos, la justicia socialy los derechos humanos fundamentales,

"Asentar las bases para una sociedad democrática y abierta en la cual el gobierno esté basado en la voluntad del pueblo y cada ciudadano sea igualmente protegido por la ley;

"Mejorat la calidad de vida de todos los ciudadanos y liberar el potencial de cada persona; y

"Construir una Sud África unida y democrática capaz de asumir su lugar adecuado como un Estado soberano en la familia de las naciones" (...).

Su Art. $1^{\circ}$ dice:

"La República de Sud África es un Estado único, soberano y democrático fundado en los siguientes valores:

“(a) La dignidad humana, el logro de la igualdad y el progreso de los derechos humanos y libertades" (...)

El Art. 7.1. contenido en el Cap. de la Carta de Derechos, prescribe:

"Esta Carta de Derechos es la piedra angular de la democracia en Sud Africa. Ella protege los derechos de todas las personas en nuestro país y afirma los valores democráticos de la dignidad humana, la igualdad y la libertad".

\section{Ley Fundamental sobre Dignidad Humana y Libertad, de Israel (1992)}

Esta Ley Constitucional, complementada por la enmienda No 5752-1992, en su Sección 1, dice aś:

\section{"Principios Básicos:}

"1. Los Derechos Fundamentales en Israel están basados sobre el reconocimiento del valor del ser humano, la santidad de la vida humana, y el principio de que todas las personas son libres; estos derechos deberán sustentarse en el espíritu que anima la declaración del establecimiento del Estado de Istael." 
“1(a) El propósito de esta Ley Fundarnental es proteger la dignidad humana y la libertad, en orden a establecer en una ley de este carácter los valores del Estado de Israel como un Estado judío y democrático.

"2. Todas las personas son titulares de la protección de su vida, cuerpo y dignidad."

\section{Trascendencia de los Valores en el Derecho Constitucional y en las Relaciones entre los Estados}

43. Sabemos ya que los valores impregnan todo el vasto mosaico de la actividad humana y -dentro de él- las relaciones jurídicas.

Cabe preguntarse: ¿̨ué importancia tienen los valores jurldicos?; ¿̨qué elementos agregan a los que la técnica legislativa utiliza en la elaboración de las normas?

Al menos, pueden identificarse tres aportes de los valores jurídicos: A. Ellos sirven de clara ortentación para averiguar el sentido y la finalidad de las normas; B. Proporcionan criterios certeros para interpretarlas; C. Además, proporcionan los elementos necesarios para integrar las lagunas o vacíos del ordenamiento jurídico.

Pero no es en el campo de la técnica jurídica donde los valores juegan su papel más importante.

Como la más alta floración de la cultura, los valores no son cualidades estimables para declararlas o para admirarlas desde la lejanta. Los valores valen cuando se asumen, cuando se incorporan al ser y al obrar de las personas, de los operadores jurídicos y de los órganos de poder estatales e internacionales.

En resumen, o los valores se viven o carecen de toda importancia.

44. A comienzos del siglo XXI, la humanidad asiste a una confrontación entre la observancia de los valores que propugnan los instrumentos internacionales y las Constituciones Políticas, por una parte; y, por la otra, los intereses económicos, las estrategias de producción y de mercado y las acciones brutales de algunos gobiernos que arrasan con los valores cuando así conviene a sus pretensiones políticas o a sus sueños hegemónicos. Esta confrontación no es un asunto menor pues de su resultado depende la suerte de nuestro planeta y el destino de la humanidad.

45. Últimamente, un grupo importante de personas de todos los países han elaborado La carta de la Tierra, que alerta sobre las contradicciones existentes en el mundo e 
interpela a las personas, a las organizaciones y a los gobiernos para superarlas, renovando su compromiso con los valores que, a veces, se olvidan o se ignoran. ${ }^{27}$

46. En el campo de la medicina, la Federación Europea de Medicina Interna, el American College of Phisicians, la American Society of Internal Medicine y el American Board de la misma especialidad, han elaborado un estatuto para el ejercicio de la medicina, el que -junto con plantear sus problemas e indicar los principios adecuados para resolverlos- hace ver la necesidad de reafirmar los principios $y$ valores universales de esa profesión ${ }^{28}$.

47. El Parlamento de las Religiones del Mundo, reunido en asamblea en el Grant Park de Chicago (1993), emitió una declaración estremecedora de la cual transcribimos parte de su lntroducción:

"El mundo agoniza. Agonía tan penetrante y opresiva que nos sentimos movidos a seńalar las formas en que se muestra para poner de manifiesto lo hondo de nuestra zozobra.

"La paz nos da la espalda. El planeta está siendo destruido. Los vecinos viven en el temor mutuo. Hombres y mujeres se distancian entre sí. Los niños mueren. Todo ello es terribie.

"Condenamos el mal uso de los ecosistemas de nuestra tierra.

"Condenamos la miseria que estrangula las posibilidades de vida; el hambre, que debilita los cuerpos de los seres humanos; las desigualdades económicas, que a tantas familias amenazan con la ruina.

27 El Preámbulo de la Carta cermina diciendo: "necesitamos urgentemente una visión compartida sobre los valores básicos que brinden un fundamento écico para la comuridad mundial emergente. Por lo tanto, juntos y con una gran esperanza, afirmamos los siguientes principios interdependientes, para una forma de vida sastenibie, como un fundamento común mediante el cual se deberá gular y valorar la conducta de las personas, organizaciones, empresss, gobiernos $\mathrm{e}$ institucianes transnacionales". Sigue a continuacion un lisrado de principios que abarcan el Respeto y Cuidado de la Comunidad de la Vida, la Integridad Ecológica, la justicia Sacial y Econónica, la Democracia, la no Violencia y la Paz. La Carta termina ast: “Todo individuo, familia, organización y comunidad, tienen un papel vital que eumplir. Las artes, las ciencias, las religiones, las instituciones educativas, los medios de comunicación, las empresos, las organizaciones no gubernamentales y los gobiennos están Llamados a ofrecer un liderazgo crearivo. La aliznza entre gobiemos, sociedad civil y empress, es esencial para la gobernabilidad efecriva. / Con el objeto de construir una comunidad global sustentabie, las naciones del mundo deben renovar su compromiso con las Naciones Unidas, cumplir con sus obligaciones bajo los acuetdos internacionales exisrentes y apoyar la implementación de los principios de la Carta de la Tierra, por medio de ur instrumento internacional legalmente vinculante sobre medio ambiente y desarrollo. / Que el nuestro sca un tiempo que se tecuerde por el desperzar de una nueva reverencia ante la vida, por la firme resolución de aleanzar la sustencabilidad; por el aceleramiento en la lucha por iz justicia y la paz y por la alegre celebración de la vida ${ }^{n}$. The Earsh Charter Initiative. The Earth Councih Apdo. 2323-1002, San Jose, Casta Rica. Enaili infoecarthcharter.org

28 El Preámbulo del Estatuto schiala en uno de sus pátrafos: "Actualmente la profesión médica se ve enfrentada a unz explosión tecrológica, a futerzas del mereado cambiantes, a problemas en el otorgamiento de presraciones de salud, al bioterrorisno y a la globalizactín. Resultadn de ello es que los médicos encuenuran cada vez más diffcil satisfacet sus responsabilidades con los pacientes $y$ con la saciedad. En esras circunstancias, reafirmar los principios y valores fundrmentales y unitersales de la profesión médica, que siguen siendo ideales procurados por todos los médicos, resula ser de la mayor importancian". Revista Médice de Chile, 2003, 131: 457-460. 
"Condenamos el desorden social de las naciones; el desprecio de la justicia, que empuja a ciudadanos hacia la marginación; la anarquía, que gana posiciones en nuestras comunidades; y la absurda muerte de niños mediante la violencia. Condenamos especialmente la agresión y el odio en nombre de la religión. Esta agonía debe cesar.

"Debe cesar, porque ya existe la base de una ética. Tal ética brinda la posibilidad de un mejor orden individual y global que aleje a los hombres de la desesperación y a las naciones del caos (...)

"Afrrmamos que las enseñanzas de las religiones contienen un patrimonio común de valores radicales que constituyen la base de una ética mundial".

48. Todas estas voces, Llamadas a sacudir la conciencia de la humanidad - sumadas a la reacción universal del mundo político, de la élite intelectual y del periodismo analítico ante las invasiones de Afganistán y de Iraq-, nos alertan acerca de las graves circunstancias por las que atraviesa la vigencia de los valores en la época actual.

Nada podŕa ser más funesto para la suerte de la tierra y de la humanidad que la habita, que la degradación del fruto más delicado, más elaborado, más difundido y más apetecible de la cultura universal como son sus valores.

Porque su olvido o su desprecio -esto es, la desvalorización de los valores- haría realidad la teoría de Nietzsche, desarrollada por Spengler, en el sentido de que el momento culminante del desarrollo de una civilización marca el inicio de su comupción y su decrepitud.

Porque -como dijimos al comienzo- la principal característica de los valores es su alta carga afectiva. La vida adquiere el valor de los valores con que se vive. $Y$ es por eso que, gracias a ellos, vale la pena vivir; y hay veces en que, también por ellos, vale la pena morir. 